\title{
Kategorie zachowań zdrowotnych pacjentów przed wystąpieniem zawału mięśnia sercowego w zależności od wybranych zmiennych socjodemograficznych
}

\section{Categories of health behaviors of patients before the onset of myocardial infarction depending on selected sociodemographic variables}

\author{
NATALIA CECOT ${ }^{1}$, DARIA KAŃKOWSKA ${ }^{2}$ \\ 1 Państwowa Uczelnia Zawodowa we Włocławku, Instytut Nauk o Zdrowiu \\ 2 Szpital Wielospecjalistyczny im. dr. Ludwika Błażka w Inowrocławiu, Oddział Kardiolo- \\ gii i Oddział Intensywnego Nadzoru Kardiologicznego
}

\section{Streszczenie}

Wstęp. Zawał mięśnia sercowego zalicza się do grupy ostrych zespołów wieńcowych. Jest to grupa schorzeń, która cechuje się wystąpieniem zaburzeń w krążeniu wieńcowym, co prowadzi do ograniczenia lub całkowitego ustania przepływu krwi w tętnicach wieńcowych. Ostry zawał serca są najczęstszą przyczyną zgonów osób poniżej 75 roku życia w Polsce, ale także w Europie.

Cel. Celem niniejszej pracy była ocena kategorii zachowań zdrowotnych pacjentów przed wystąpieniem zawału mięśnia sercowego w zależności od wybranych zmiennych socjodemograficznych. Czynniki ryzyka zawału mięśnia sercowego można podzielić na dwie grupy: modyfikowalne (zależne) i niemodyfikowalne (niezależne). Do czynników, które zależą od stylu życia człowieka zalicza się: zaburzenia lipidowe, palenie tytoniu, nadwagę, nadciśnienie tętnicze, cukrzycę, stres oraz nadmierne spożywanie alkoholu. Czynniki niemodyfikowalne to płeć, wiek oraz czynniki genetyczne.

Materiał i metody. Materiał badań stanowiły osoby po przebytym zawale mięśnia sercowego. Było to stu pacjentów hospitalizowanych w Oddziale Kardiologii i Oddziale Intensywnego Nadzoru Kardiologicznego w Szpitalu Wielospecjalistycznym im. dr. Ludwika Błażka w Inowrocławiu. Wybrano metodę 
szacowania, zastosowano technikę badawczą w postaci ankiety. Narzędziem badawczym wykorzystanym w pracy był kwestionariusz Inwentarza Zachowań Zdrowotnych oraz autorska metryczka.

Wyniki. Prawidłowe nawyki żywieniowe oraz pozytywne nastawienie psychiczne było prezentowane na takim samym poziomie zarówno wśród kobiet, jak i mężczyzn. Kobiety uzyskiwały wyższe wyniki w kategorii zachowań profilaktycznych niż mężczyźni. Odwrotnie proporcjonalne wyniki uzyskano w kategorii praktyki zdrowotne. Respondenci z wykształceniem zawodowym osiągali najwyższe wyniki spośród innych respondentów w kategorii określającej prawidłowe nawyki żywieniowe. Najwyższy wskaźnik zachowań profilaktycznych odnotowano z kolei u osób z wykształceniem średnim. Ankietowani z wyższym wykształceniem osiągnęli najwyższy wskaźnik dotyczący pozytywnego nastawienia psychicznego oraz praktyk zawodowych. Wśród ankietowanych największy wskaźnik w kategorii prawidłowych nawyków żywieniowych oraz praktyk zdrowotnych osiągnęły osoby rozwiedzione. Zachowania profilaktyczne były najwyższe u osób pozostających w związku małżeńskim. Panny/kawalerowie uzyskiwali najwyższe wyniki w kategorii pozytywne nastawienie psychiczne. W badaniach własnych analizując kategorie zachowań ze względu na wiek respondentów można wywnioskować, że wraz z zaawansowaniem wieku wzrastała również wiedza i świadomość odnośnie prawidłowych nawyków żywieniowych. Jednak im niższy był wiek respondentów, tym wyższy prezentowali poziom zachowań profilaktycznych. Pozytywne nastawienie psychiczne było najwyżej punktowane wśród ankietowanych w wieku 20-59 lat. Z kolei najwyższy wskaźnik praktyk zdrowotnych osiągnęli najstarsi respondenci.

Wnioski. W kategorii prawidłowe nawyki żywieniowe najwyższy wskaźnik osiągały osoby z wykształceniem zawodowym oraz osoby rozwiedzione, zarówno kobiety, jak i mężczyźni. Najwyższy wskaźnik zachowań profilaktycznych odnotowano u kobiet, osób z wykształceniem średnim oraz osób pozostających w związku małżeńskim. Osoby z wyższym wykształceniem, panny i kawalerowie, osoby w przedziale wiekowym 20-59 lat osiągnęły najwyższy wskaźnik pozytywnego nastawienia psychicznego. W kategorii praktyki zdrowotne najwyższy wskaźnik osiągnęli mężczyźni, osoby z wyższym wykształceniem, rozwiedzione i najstarsi respondenci. Wraz z zaawansowaniem wieku wzrastała wiedza i świadomość prawidłowych nawyków żywieniowych. Nato- 
miast im niższy wiek respondentów, tym wyższy prezentowali poziom zachowań profilaktycznych.

Słowa kluczowe: kategorie zachowań zdrowotnych, zmienne socjodemograficzne, zawał mięśnia sercowego

\begin{abstract}
Admission. Myocardial infraction belongs to group of acute coronary syndromes which are characterized by disturbances in the coronary circulatory systems. That leads to reduction or limitation of blood flow in coronary artery.

Aim. Purpose of this study was assessment of patients health before myocardial infraction depending on sociodemographic variables. Risk factors of myocardial infraction can be split into two different groups: modifiable(dependent) and not modifiable (independent). Factors that depends on human lifestyle are divided to: lipid disorders, smoking, overweight, hypertension, diabetes, stress and excessive alcohol consumption. Independent factors are split to gender, age and genetic conditions.
\end{abstract}

Material and methods. Research has been conducted on group of one hundred patients with recognized myocardial hearth attack hospitalized in Department of Cardiology and the Department of Intensive Cardiac Supervision in the name of Ludwik Błażek in Inowroclaw. In this study method that has been used is estimation method. Data from the patients has been taken in questionnaire form. The research tool used in the study was the Health Behavior Inventory questionnaire and the author's record.

Results. Proper eating habits and positive mental attitude was presented on a same level both in women and man. Women reached higher level in preventive behaviors than men's. Inverted results has been reached in healthy practices category. Respondents with vocational had the best results in proper eating habitats category. The highest preventive behavior level has been observed in group with secondary education. Respondents with high education level reached the higher result in positive mental attitude. The higher level on proper eating habitats has been observed in a group of divorced people. Preventive habitats reached the highest level in a group of married people. Singles reached the highest results in mental attitude category. In own research we can observe that consciousness on eating habitats increasing in line with human age. The 
lower respondents age was, higher preventive behavior level they showed. Positive mental habitats has been observed as the highest one in respondents between 20 and 59 years old. The highest results on health practice index has been obtained by the oldest group of responders.

Conclusions. In eating habits category people divorced (men and women) and with vocational education earned the highest indicators. The highest rate of prophylactic behavior was recorded in women, people with secondary education and people who were married. People with higher education, singles, and persons of age between 20 and 59 years old obtained the highest indicator of positive mental attitude. In category of health practices highest indicator has been obtained by men, persons with higher education, divorced people, and the oldest respondents. With the advancement of age, the knowledge and awareness of proper eating habits grew. On the other hand, the increase in prophylactic behavior increased with the decrease in the age of the respondents.

Keywords: Health behavior category, sociodemographic variables, myocardial infraction

\section{Wstęp}

Zawał mięśnia sercowego zalicza się do grupy ostrych zespołów wieńcowych. Jest to grupa schorzeń, która cechuje się wystąpieniem zaburzeń w krążeniu wieńcowym, co prowadzi do ograniczenia lub całkowitego ustania przepływu krwi w tętnicach wieńcowych. Charakteryzuje się on bólem w klatce piersiowej o charakterze dławicowym i stanowi bezpośredni stan zagrożenia życia [1].

Choroby sercowo-naczyniowe, w tym ostry zawał serca są najczęstszą przyczyną zgonów osób poniżej 75 roku życia w Polsce, ale także w Europie [2]. Wyróżnia się zawał serca: z uniesieniem odcinka ST (tzw. STEMI - ST-elevation myocardial infraction), co świadczy o całkowitym zamknięciu tętnicy wieńcowej i ustaniu przepływu krwi; bez uniesienia odcinka ST (tzw. NSTEMI - non-ST-myocardial infraction), czyli z krytycznym ograniczeniem przepływu krwi przez tętnicę wieńcową [3]. Zawał mięśnia sercowego może mieć różne przyczyny. Może być wywołany przez zmiany miażdżycowo-zakrzepowe, brakiem 
równowagi pomiędzy podażą a zapotrzebowaniem na tlen wynikającą ze specyficznych sytuacji klinicznych. Ponadto ostry zespół wieńcowy może być spowodowany powikłaniami po przezskórnej interwencji wieńcowej, takimi jak zakrzepica lub restenoza w stencie [4]. Czynniki ryzyka zawału mięśnia sercowego można podzielić na dwie grupy: modyfikowalne (zależne) i niemodyfikowalne (niezależne). Do czynników, które zależą od stylu życia człowieka zalicza się: zaburzenia lipidowe, palenie tytoniu, nadwagę, nadciśnienie tętnicze, cukrzycę, stres oraz nadmierne spożywanie alkoholu. Czynniki niemodyfikowalne to płeć, wiek oraz czynniki genetyczne [4].

\section{Cel}

Celem niniejszej pracy była ocena kategorii zachowań zdrowotnych pacjentów przed wystąpieniem zawału mięśnia sercowego w odniesieniu do wybranych czynników socjodemograficznych (wiek, miejsce zamieszkania, płeć, stan cywilny, wykształcenie, status zawodowy).

\section{Materiał i metody}

Materiał badań stanowiły osoby po przebytym zawale mięśnia sercowego. Było to stu pacjentów hospitalizowanych w Oddziale Kardiologii i Oddziale Intensywnego Nadzoru Kardiologicznego w Szpitalu Wielospecjalistycznym im. dr. Ludwika Błażka w Inowrocławiu. Wybrano metodę szacowania, zastosowano technikę badawczą w postaci ankiety. Narzędziem badawczym wykorzystanym w pracy był kwestionariusz Inwentarza Zachowań Zdrowotnych oraz autorska metryczka.

\section{Wyniki}

Zachowania zdrowotne ankietowanych podzielono na cztery kategorie, tj.: prawidłowe nawyki żywieniowe, zachowania profilaktyczne, pozytywne nastawienie psychiczne oraz praktyki zdrowotne. 
Tabela 1. Rozkład kategorii zachowań zdrowotnych wśród badanych w zależności od płci.

\begin{tabular}{|c|c|c|c|c|c|c|c|c|}
\hline & \multicolumn{4}{|c|}{ Kobiety } & \multicolumn{4}{|c|}{ Mężczyźni } \\
\hline & 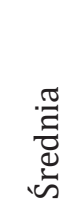 & 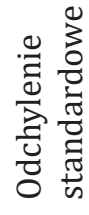 & $\mathrm{n}$ & [\%] & 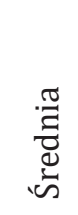 & 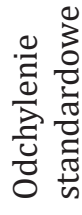 & $\mathrm{n}$ & [\%] \\
\hline $\begin{array}{l}\text { prawidłowe } \\
\text { nawyki } \\
\text { żywieniowe }\end{array}$ & 2,66 & 0,87 & 3 & 9 & 2,94 & 0,6 & 7 & 10 \\
\hline $\begin{array}{l}\text { zachowania } \\
\text { profilaktyczne }\end{array}$ & 2,92 & 0,81 & 6 & 18 & 3,33 & 0,77 & 4 & 6 \\
\hline $\begin{array}{l}\text { pozytywne } \\
\text { nastawienie } \\
\text { psychiczne }\end{array}$ & 3,29 & 0,59 & 3 & 9 & 3,42 & 0,71 & 7 & 10 \\
\hline $\begin{array}{l}\text { praktyki } \\
\text { zdrowotne }\end{array}$ & 3,29 & 1,09 & 1 & 3 & 3,49 & 0,61 & 4 & 6 \\
\hline
\end{tabular}

W tabeli 1. przedstawiono podział kategorii zachowań zdrowotnych zależny od płci respondentów. Wśród kobiet i mężczyzn w poszczególnych kategoriach zachowań zdrowotnych średnia wyników oscylowała wokół wartości 3. Największy odsetek kobiet (19\%, $\mathrm{n}=6$ ) wykazywał zachowania profilaktyczne, natomiast najmniejszy praktyki zdrowotne $(3 \%, \mathrm{n}=1)$. W grupie mężczyzn takie same wyniki uzyskano w kategoriach: prawidłowe nawyki żywieniowe i pozytywne nastawienie psychiczne $(10 \%, \mathrm{n}=7)$. W pozostałych kategoriach wyniki rozkładały się następująco: po 6\% mężczyzn $(n=4)$. 
Tabela 2. Rozkład kategorii zachowań zdrowotnych w zależności od miejsca zamieszkania badanych.

\begin{tabular}{|c|c|c|c|c|c|c|c|c|}
\hline & \multicolumn{4}{|c|}{ Wieś } & \multicolumn{4}{|c|}{ Miasto } \\
\hline & 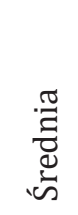 & 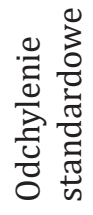 & $\mathrm{n}$ & [\%] & 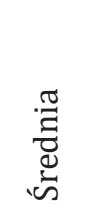 & 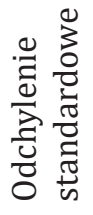 & $\mathrm{n}$ & [\%] \\
\hline $\begin{array}{l}\text { prawidłowe } \\
\text { nawyki } \\
\text { żywieniowe }\end{array}$ & 2,82 & 1,04 & 3 & 9 & 2,72 & 0,61 & 7 & 11 \\
\hline $\begin{array}{l}\text { zachowania } \\
\text { profilaktyczne }\end{array}$ & 3,11 & 0,92 & 1 & 3 & 3,03 & 0,75 & 9 & 14 \\
\hline $\begin{array}{l}\text { pozytywne } \\
\text { nastawienie } \\
\text { psychiczne }\end{array}$ & 3,33 & 0,71 & 4 & 12 & 3,43 & 0,58 & 6 & 9 \\
\hline $\begin{array}{l}\text { praktyki } \\
\text { zdrowotne }\end{array}$ & 3,23 & 0,77 & 1 & 3 & 3,44 & 1,06 & 4 & 6 \\
\hline
\end{tabular}

W tabeli 2. zaprezentowano rozkład kategorii zachowań zdrowotnych w zależności od miejsca zamieszkania osób ankietowanych. We wszystkich kategoriach zachowań zdrowotnych bez względu na miejsce zamieszkania średnie wyniki był zbliżone do wartości 3. Wśród ankietowanych zamieszkujących na wsi największy odsetek osób $(12 \%, n=4)$ wykazywał pozytywne nastawienie psychiczne. Tylko 3\% respondentów ( $\mathrm{n}=1$ ), którzy mieszkają na wsi wskazywało na zachowania profilaktyczne oraz praktyki zdrowotne. Największa liczba respondentów mieszkających w mieście (14\%, n=9) wykazywało zachowania profilaktyczne. Tylko $6 \%(\mathrm{n}=4)$ osób deklarujących życie w mieście przejawiało praktyki zdrowotne. 
Tabela 3. Rozkład kategorii zachowań zdrowotnych w zależności od wykształcenia podstawowego i zawodowego badanych.

\begin{tabular}{|c|c|c|c|c|c|c|c|c|}
\hline & \multicolumn{4}{|c|}{ Podstawowe } & \multicolumn{4}{|c|}{ Zawodowe } \\
\hline & $\begin{array}{l}\stackrel{\pi}{\Xi} \\
\frac{0}{0} \\
\stackrel{0}{\omega}\end{array}$ & 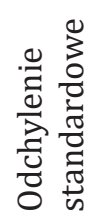 & $\mathrm{n}$ & {$[\%]$} & $\begin{array}{l}\stackrel{\pi}{\Xi} \\
\frac{0}{0} \\
\stackrel{\omega}{\omega}\end{array}$ & 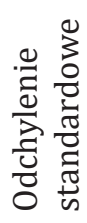 & $\mathrm{n}$ & {$[\%]$} \\
\hline $\begin{array}{l}\text { prawidłowe } \\
\text { nawyki } \\
\text { żywieniowe }\end{array}$ & 2,67 & 0,55 & 1 & 5 & 2,65 & 0,68 & 7 & 14 \\
\hline $\begin{array}{l}\text { zachowania } \\
\text { profilaktyczne }\end{array}$ & 3,42 & 0,90 & 1 & 5 & 2,84 & 0,82 & 1 & 2 \\
\hline $\begin{array}{l}\text { pozytywne } \\
\text { nastawienie } \\
\text { psychiczne }\end{array}$ & 3,50 & 0,75 & 2 & 10 & 3,21 & 0,63 & 6 & 12 \\
\hline $\begin{array}{l}\text { praktyki } \\
\text { zdrowotne }\end{array}$ & 3,66 & 0,47 & 1 & 5 & 3,32 & 1,23 & 2 & 4 \\
\hline
\end{tabular}

Tabela 4. Rozkład kategorii zachowań zdrowotnych w zależności od wykształcenia średniego i wyższego badanych.

\begin{tabular}{|c|c|c|c|c|c|c|c|c|}
\hline & \multicolumn{4}{|c|}{ Średni } & \multicolumn{4}{|c|}{ Wyższe } \\
\hline & : & 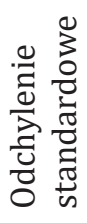 & $\mathrm{n}$ & [\%] & . & 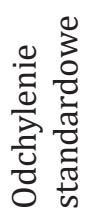 & $\mathrm{n}$ & {$[\%]$} \\
\hline $\begin{array}{l}\text { prawidłowe } \\
\text { nawyki } \\
\text { żywieniowe }\end{array}$ & 2,90 & 1,15 & 2 & 10 & 3,19 & 0,86 & 0 & 0 \\
\hline $\begin{array}{l}\text { zachowania } \\
\text { profilaktyczne }\end{array}$ & 3,03 & 0,61 & 3 & 15 & 3,44 & 0,90 & 1 & 11 \\
\hline $\begin{array}{l}\text { pozytywne } \\
\text { nastawienie } \\
\text { psychiczne }\end{array}$ & 3,36 & 0,47 & 0 & 0 & 3,57 & 0,61 & 2 & 22 \\
\hline $\begin{array}{l}\text { praktyki } \\
\text { zdrowotne }\end{array}$ & 3,1 & 0,58 & 1 & 5 & 3,48 & 0,69 & 1 & 11 \\
\hline
\end{tabular}


W tabeli 3. oraz 4. zaprezentowano rozkład kategorii zachowań zdrowotnych w zależności od wykształcenia respondentów. Największy odsetek osób z wykształceniem podstawowym $(10 \%, n=2)$ przejawiało pozytywne nastawienie psychiczne. Takie zachowanie wykazywało również $12 \%(n=6)$ respondentów z wykształceniem zawodowym oraz $22 \%$ ankietowanych z wykształceniem wyższym. Wśród osób deklarujących wykształcenie zawodowe największy odsetek respondentów $(14 \%, n=7)$ odznaczał się prawidłowymi nawykami żywieniowymi.

Tabela 5. Rozkład kategorii zachowań zdrowotnych w zależności od stanu cywilnego badanych.

\begin{tabular}{|c|c|c|c|c|c|c|c|c|}
\hline & \multicolumn{4}{|c|}{ Kawaler / Panna } & \multicolumn{4}{|c|}{ Rozwiedziony/-na } \\
\hline & 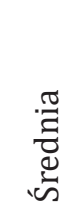 & 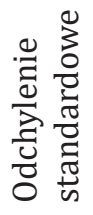 & $\mathrm{n}$ & [\%] & $\begin{array}{l}\stackrel{\pi}{\Xi} \\
\frac{0}{0} \\
\omega\end{array}$ & 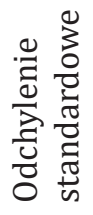 & $\mathrm{n}$ & [\%] \\
\hline $\begin{array}{l}\text { prawidłowe } \\
\text { nawyki } \\
\text { żywieniowe }\end{array}$ & 2,43 & 0,69 & 0 & 0 & 2,82 & 0,55 & 4 & 16 \\
\hline $\begin{array}{l}\text { zachowania } \\
\text { profilaktyczne }\end{array}$ & 2,61 & 0,66 & 2 & 10 & 3,33 & 0,69 & 2 & 8 \\
\hline $\begin{array}{l}\text { pozytywne } \\
\text { nastawienie } \\
\text { psychiczne }\end{array}$ & 3,03 & 0,58 & 4 & 20 & 3,49 & 0,49 & 1 & 4 \\
\hline $\begin{array}{l}\text { praktyki } \\
\text { zdrowotne }\end{array}$ & 2,95 & 0,72 & 1 & 5 & 3,44 & 0,58 & 2 & 8 \\
\hline
\end{tabular}


Tabela 6. Rozkład kategorii zachowań zdrowotnych w zależności od stanu cywilnego badanych.

\begin{tabular}{|c|c|c|c|c|}
\hline & \multicolumn{4}{|c|}{ Żonaty / Mężatka } \\
\hline & 范 & 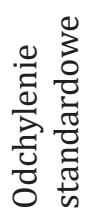 & $\mathrm{n}$ & [\%] \\
\hline $\begin{array}{l}\text { prawidłowe } \\
\text { nawyki } \\
\text { żywieniowe }\end{array}$ & 2,85 & 0,92 & 5 & 9 \\
\hline $\begin{array}{l}\text { zachowania } \\
\text { profilaktyczne }\end{array}$ & 3,09 & 0,87 & 6 & 11 \\
\hline $\begin{array}{l}\text { pozytywne } \\
\text { nastawienie } \\
\text { psychiczne }\end{array}$ & 3,37 & 0,68 & 5 & 9 \\
\hline $\begin{array}{l}\text { praktyki } \\
\text { zdrowotne }\end{array}$ & 3,47 & 1,14 & 2 & 4 \\
\hline
\end{tabular}

W tabeli 5. oraz 6. przedstawiono rozkład kategorii zachowań zdrowotnych w zależności od stanu cywilnego respondentów. Pozytywne nastawienie psychiczne wykazywało $20 \%$ osób (n=4), które swój stan cywilny określiły jako kawaler/panna. Wśród tych osób 10\% (n=2) demonstrowało zachowania profilaktyczne, a także 5\% z nich $(\mathrm{n}=1)$ przejawiało praktyki zdrowotne. Wśród rozwiedzionych ankietowanych najwięcej osób $(16 \%, n=4)$ zaliczało się do kategorii prawidłowe nawyki żywieniowe. Najmniej osób z tej grupy respondentów $(4 \%, n=1)$ przejawiało pozytywne nastawienie psychiczne. Osoby ankietowane, które pozostawały w związku małżeńskim, deklarowało zachowania profilaktyczne $(11 \%, n=6)$. 
Tabela 7. Rozkład kategorii zachowań zdrowotnych w zależności od statusu zawodowego badanych.

\begin{tabular}{|c|c|c|c|c|c|c|c|c|}
\hline & \multicolumn{4}{|c|}{ Bezrobotny/-na } & \multicolumn{4}{|c|}{ Pracujący/-ca } \\
\hline & $\frac{\pi}{\Xi}$ & 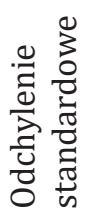 & $\mathrm{n}$ & [\%] & .ేّ & 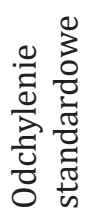 & $\mathrm{n}$ & [\%] \\
\hline $\begin{array}{l}\text { prawidłowe } \\
\text { nawyki } \\
\text { żywieniowe }\end{array}$ & 2,37 & 0,59 & 2 & 10 & 2,56 & 0,83 & 0 & 0 \\
\hline $\begin{array}{l}\text { zachowania } \\
\text { profilaktyczne }\end{array}$ & 2,45 & 0,57 & 2 & 10 & 2,83 & 0,77 & 1 & 4 \\
\hline $\begin{array}{l}\text { pozytywne } \\
\text { nastawienie } \\
\text { psychiczne }\end{array}$ & 3,02 & 0,68 & 3 & 15 & 3,28 & 0,67 & 4 & 16 \\
\hline $\begin{array}{l}\text { praktyki } \\
\text { zdrowotne }\end{array}$ & 2,85 & 0,52 & 1 & 5 & 3,32 & 1,12 & 1 & 4 \\
\hline
\end{tabular}

Tabela 8. Rozkład kategorii zachowań zdrowotnych w zależności od statusu zawodowego badanych.

\begin{tabular}{|c|c|c|c|c|}
\hline & \multicolumn{4}{|c|}{ Emeryt } \\
\hline & $\begin{array}{l}\stackrel{\pi}{\Xi} \\
\frac{0}{0} \\
\stackrel{0}{5}\end{array}$ & 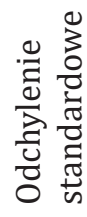 & $\mathrm{n}$ & [\%] \\
\hline $\begin{array}{l}\text { prawidłowe } \\
\text { nawyki } \\
\text { żywieniowe }\end{array}$ & 2,95 & 0,79 & 9 & 18 \\
\hline $\begin{array}{l}\text { zachowania } \\
\text { profilaktyczne }\end{array}$ & 3,34 & 0,78 & 4 & 8 \\
\hline $\begin{array}{l}\text { pozytywne } \\
\text { nastawienie } \\
\text { psychiczne }\end{array}$ & 3,46 & 0,57 & 3 & 6 \\
\hline $\begin{array}{l}\text { praktyki } \\
\text { zdrowotne }\end{array}$ & 3,53 & 0,89 & 1 & 2 \\
\hline
\end{tabular}


W tabeli 7. oraz 8. przedstawiono rozkład kategorii zachowań zdrowotnych w zależności od statusu zawodowego ankietowanych. Pozytywne nastawienie psychiczne przejawiało 15\% (n=3) osób bezrobotnych, $16 \%(n=4)$ osób pracujących, natomiast tylko $6 \%(n=3)$ respondentów przebywających na emeryturze. Największą wagę do prawidłowych nawyków żywieniowych, których wartości oscylowały wokół średniej zauważono wśród emerytów $(18 \%, n=9)$.

Tabela 9. Rozkład kategorii zachowań zdrowotnych w zależności od wieku badanych.

\begin{tabular}{|c|c|c|c|c|c|c|c|c|}
\hline & \multicolumn{4}{|c|}{ 20-59 r.ż. } & \multicolumn{4}{|c|}{ 60-74 r.ż. } \\
\hline & 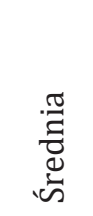 & 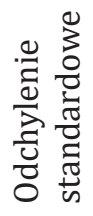 & $\mathrm{n}$ & [\%] & 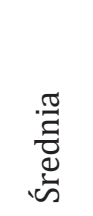 & 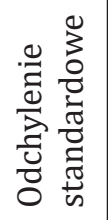 & $\mathrm{n}$ & {$[\%]$} \\
\hline $\begin{array}{l}\text { prawidłowe } \\
\text { nawyki } \\
\text { żywieniowe }\end{array}$ & 2,46 & 0,81 & 2 & 8 & 2,85 & 0,94 & 4 & 10 \\
\hline $\begin{array}{l}\text { zachowania } \\
\text { profilaktyczne }\end{array}$ & 2,54 & 0,73 & 5 & 18 & 3,09 & 0,64 & 4 & 10 \\
\hline $\begin{array}{l}\text { pozytywne } \\
\text { nastawienie } \\
\text { psychiczne }\end{array}$ & 2,99 & 0,7 & 4 & 14 & 3,34 & 0,52 & 4 & 10 \\
\hline $\begin{array}{l}\text { praktyki } \\
\text { zdrowotne }\end{array}$ & 2,87 & 0,71 & 1 & 4 & 3,5 & 1,21 & 1 & 2 \\
\hline
\end{tabular}


Tabela 10. Rozkład kategorii zachowań zdrowotnych w zależności od wieku badanych.

\begin{tabular}{|c|c|c|c|c|}
\hline & \multicolumn{4}{|c|}{ 75-99 r.ż. } \\
\hline & . & 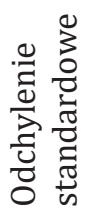 & $\mathrm{n}$ & [\%] \\
\hline $\begin{array}{l}\text { prawidłowe } \\
\text { nawyki } \\
\text { żywieniowe }\end{array}$ & 2,90 & 0,47 & 5 & 16 \\
\hline $\begin{array}{l}\text { zachowania } \\
\text { profilaktyczne }\end{array}$ & 3,49 & 0,84 & 1 & 3 \\
\hline $\begin{array}{l}\text { pozytywne } \\
\text { nastawienie } \\
\text { psychiczne }\end{array}$ & 3,64 & 0,55 & 3 & 10 \\
\hline $\begin{array}{l}\text { praktyki } \\
\text { zdrowotne }\end{array}$ & 3,62 & 0,54 & 3 & 10 \\
\hline
\end{tabular}

W tabeli 9. oraz 10. zaprezentowano rozkład kategorii zachowań zdrowotnych w zależności od wieku respondentów. Wśród ankietowanych, których wyniki oscylowały w okolicy średniej największy odsetek przejawiający prawidłowe nawyki żywieniowe deklarowały osoby w przedziale wieku między 75-99 r.ż. (16\%,n=5), natomiast najmniejszy procent - 8\% (n=4) wśród najmłodszej grupy badanej. Odwrotnie proporcjonalnie rozkładają się wyniki dotyczące zachowań profilaktycznych. W tej kategorii deklaracje preferowania takich zachowań dotyczyły najczęściej osób w grupie wiekowej 20-59 r.ż. (18\%, n=5), najmniejszy w najstarszej grupie ankietowanych $(3 \%, n=1)$. Pozytywne nastawienie psychiczne przejawiało $10 \%(n=3)$ osób z grupy wiekowej 75-99 r.ż., 10\% osób (n=4) w wieku 60-74 lata oraz 14\% (n=4) ankietowanych z najmłodszej grupy wiekowej. Największy odsetek osób wykazujący praktyki zdrowotne dotyczył najstarszej grupy respondentów (10\%, n=3), najmniejszy spośród osób wieku 55-74 lat (2\%, n=1). 


\section{Dyskusja}

W badaniach własnych wyróżniono 4 kategorie zachowań zdrowotnych badanych przed wystąpieniem incydentu zawału mięśnia sercowego: prawidłowe nawyki żywieniowe, zachowania profilaktyczne, pozytywne nastawienie psychiczne oraz praktyki zawodowe.

Prawidłowe nawyki żywieniowe oraz pozytywne nastawienie psychiczne było prezentowane na takim samym poziomie zarówno wśród kobiet, jak i mężczyzn. Kobiety uzyskiwały wyższe wyniki w kategorii zachowań profilaktycznych niż mężczyźni. Odwrotnie proporcjonalne wyniki uzyskano w kategorii praktyki zdrowotne. Odmienne wyniki badań zostały przedstawione w pracy Kropornickiej i współautorów [5]. Swoje wyniki opracowali w oparciu o przeprowadzone badania wśród 101 chorych na nadciśnienie tętnicze, którzy objęci byli opieką Poradni Kardiologicznej i Poradni Nadciśnienia Tętniczego w Wojewódzkim Szpitalu Specjalistycznym w Lublinie w 2015 roku. Mężczyźni uzyskiwali wyższe wyniki w kategorii zachowania profilaktyczne, pozytywne nastawienie psychiczne i praktyki zdrowotne. Kobiety minimalnie wyżej oceniały swoje prawidłowe praktyki żywieniowe.

W badaniach własnych respondenci z wykształceniem zawodowym osiągali najwyższe wyniki spośród innych respondentów w kategorii określającej prawidłowe nawyki żywieniowe. Najwyższy wskaźnik zachowań profilaktycznych odnotowano z kolei u osób z wykształceniem średnim. Ankietowani z wyższym wykształceniem osiągnęli najwyższy wskaźnik dotyczący pozytywnego nastawienia psychicznego oraz praktyk zawodowych. W badaniach przeprowadzonych przez Kawalec i współautorów [6] nie wykazano zależności pomiędzy wykształceniem respondentów a poszczególnymi kategoriami zachowań zdrowotnych. Badanie to przeprowadzono wśród 75 osób z nadwagą i otyłością na przełomie 2009-2010 roku.

W aktualnych badaniach wśród ankietowanych największy wskaźnik w kategorii prawidłowych nawyków żywieniowych oraz praktyk zdrowotnych osiągnęły osoby rozwiedzione. Zachowania profilaktyczne były najwyższe u osób pozostających w związku małżeńskim. Pan- 
ny/kawalerowie uzyskiwali najwyższe wyniki w kategorii pozytywne nastawienie psychiczne. Wyniki wspomnianych wcześniej badań Kawalec i współautorów 14 dostarczyły informacji, że stan cywilny nie wpływa na poszczególne kategorie zachowań zdrowotnych.

W badaniach własnych analizując kategorie zachowań ze względu na wiek respondentów można wywnioskować, że wraz z zaawansowaniem wieku wzrastała również wiedza i świadomość odnośnie prawidłowych nawyków żywieniowych. Jednak im niższy był wiek respondentów, tym wyższy prezentowali poziom zachowań profilaktycznych. Pozytywne nastawienie psychiczne było najwyżej punktowane wśród ankietowanych w wieku 20-59 lat. Z kolei najwyższy wskaźnik praktyk zdrowotnych osiągnęli najstarsi respondenci. Odmienne wyniki badań zostały przedstawione w pracy Kropornickiej i współautorów [5]. Autorzy wykazali bowiem wzrost poziomu zachowań zdrowotnych wraz z zaawansowaniem wieku respondentów. Pozostałe zachowania zdrowotne badanych nie różniły się istotnie statystycznie.

\section{Wnioski}

1. Kategorie zachowań zdrowotnych badanych przed wystąpieniem zawału mięśnia istotnie różniły się $\mathrm{w}$ zależności od ich płci, wykształcenia, stanu cywilnego oraz wieku.

2. W kategorii prawidłowe nawyki żywieniowe najwyższy wskaźnik osiągały osoby z wykształceniem zawodowym oraz osoby rozwiedzione, zarówno kobiety, jak i mężczyźni.

3. Najwyższy wskaźnik zachowań profilaktycznych odnotowano u kobiet, osób z wykształceniem średnim oraz osób pozostających w związku małżeńskim.

4. Osoby z wyższym wykształceniem, panny i kawalerowie, osoby w przedziale wiekowym 20-59 lat osiągnęły najwyższy wskaźnik pozytywnego nastawienia psychicznego.

5. W kategorii praktyki zdrowotne najwyższy wskażnik osiągneli mężczyźni, osoby z wyższym wykształceniem, rozwiedzione i najstarsi respondenci. 
6. Wraz z zaawansowaniem wieku wzrastała wiedza i świadomość prawidłowych nawyków żywieniowych. Natomiast im niższy wiek respondentów, tym wyższy prezentowali poziom zachowań profilaktycznych.

\section{Zalecenia dla praktyki pielęgniarskiej}

Istotnym zadaniem w praktyce pielęgniarskiej jest edukacja zdrowotna. To proces kształtowania dbałości o zdrowie własne i innych ludzi. Działania profilaktyczne mają na celu zapobieganie chorobom. Edukacja osób na temat prawidłowych nawyków żywieniowych, zachowań profilaktycznych, pozytywnego nastawienia psychicznego czy praktyk zdrowotnych może pozytywnie wpłynąć na zapobieganie zawałom mięśnia sercowego.

Pielęgniarka edukująca powinna zachęcać np. do regularnego spożywania posiłków, zwiększenia przyjmowania owoców, warzyw i produktów pełnoziarnistych, ograniczenia spożycia cukru i tłuszczów. Do edukacji zachowań profilaktycznych należą: zalecenie wykonywania aktywnmości fizycznej, rzucenie nałogu palenia papierosów, odpowiednia ilość snu, radzenie sobie ze stresem czy regularne badania kontrolne.

\section{Bibliografia/Bibliography:}

1. Kaszuba D., Nowicka A. Pielęgniarstwo kardiologiczne. Wydawnictwo Lekarskie PZWL. Warszawa 2015:110.

2. Chlebus K. i wsp. Występowanie, leczenie i prewencja wtórna zawałów w Polsce https://www.pzh.gov.pl/raport-wystepowanie-leczenie-i-prewencja-wtorna- zawalow-serca-w-polsce/ (dostęp dnia 25.11.2020).

3. Niedolaz K., Hałas K., Kaźmierczak-Dziuk A. Postępowanie z chorym po zawale serca. Pediatria i Medycyna Rodzinna. 2011;3:186-198.

4. Thygesen K., Alpert J., Jaffe A., Chaitman B., Bax J., Morrow D., White H. Czwarta uniwersalna definicja zawału serca. Kardiologia Polska. 2018;10:1391-1400. 
5. Kropornicka B. i wsp. Lifestyle in the patients suffering from hypertension. Journal of Education, Health and Sport. 2016;12:338-352.

6. Kawalec E. Reczek A., Porębska A., Brzostek T., Malinowska-Lipień I. Zachowania zdrowotne pacjentów z otyłością i nadwagą. Pielęgniarstwo XXI wieku. 2011;2:27-33. 